\title{
Power Sector of Assam: A Study on Financial Viability of State Power Utilities
}

\author{
Amit Saha ${ }^{1}$ and Martin Saha ${ }^{2}$ \\ ${ }^{1}$ Department of Management, Brainware University, Kolkata, India \\ ${ }^{2}$ Indira Gandhi National Open University, Bhopal, India
}

\section{ABSTRACT}

The power sector plays a crucial role in the development of an economy but at the same time it is also one of the neglected sectors when it comes to self adequacy and performance. The power sector reforms which came with the new Electricity Act in 2003 brought many hopes. But in the subsequent years it was only found that such reforms could hardly bring any substantial difference in the already ailing state power sector companies. Nevertheless, the country has seen significant change in coverage of household by electricity during the last few decades. Electricity has reached deep interior villages in the country and the generation of power has also increased over the years. But amidst all these developments, the financial health of the state power sector units had been completely neglected. The power sector in Assam also underwent a restructure in pursuance with the new Electricity Act of 2003 and then again in 2009 to form three units namely Assam Power Generation Corporation Limited (APGCL), Assam Electricity Grid Corporation Limited (AEGCL) and Assam Power Distribution Corporation Limited (APDCL) engaged in the generation, transmission and distribution of power respectively in the state. But it was found that the financial health of each of these power sector units was very poor. These units incurred net losses in most of the years under study. The direct costs associated with the operation of these units were found to be so high that they could not afford other administrative costs leading into losses over the years. Besides, the tariff rates were also regulated by a regulatory commission i.e., Assam Electricity Regulatory Commission which hinders the process of hiking rates to recover costs. Further, the structure of long term funds and assets also reflected a poor condition with piling receivables and payables in these companies. Such high payables are leading to a negative net working capital and the companies are using its long term borrowings to fulfil its deficit in working capital. There is common notion that these companies are utility service providers of the public and their profitability are not a matter of concern. The real purpose is to provide electricity to every nook and corner of the country. But it must also be understood that losses are not an answer to service. Mounting losses are only depleting funds and in addition to that it becomes difficult to track their operational performance.

\section{KEY WORDS: RESTRUCTURE, TARIFF, REFORMS, DEFICIT, PROFITABILITY.}

\section{INTRODUCTION}

The power industry is the life blood of an economy be it an emerged economy or a developing economy. Sound and stable growth is always dependent upon its basic infrastructure which includes power. The economic progress in the past few decades has seen millions of people enjoy major improvements in their standard of living and material well-being and most of these changes

Biosc Biotech Res Comm P-ISSN: 0974-6455 E-ISSN: 2321-4007

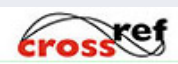

Identifiers and Pagination

Year: 2021 Vol: 14 No (5) Special Issue

Pages: $270-276$

This is an open access article under Creative

Commons License Attribn 4.0 Intl (CC-BY).

DOI: http://dx.doi.org/10.21786/bbrc/14.5/49 have been particularly visible in the emerging economies. Although, globalization and market liberalization have underpinned these developments, but we must not undermine the crucial role played by the power sector. Without power no country can build or run the factories and cities that provides for goods and services or jobs and businesses nor the basic amenities that make living a life more comfortable and enjoyable. Power is the "oxygen" that pumps the economy and is the life-blood of growth and development in this mass industrialization phase that emerging economic giants are passing through.

Statement of the Problem: The power sector has a pivotal role in the race of economic development. Therefore, the efficiency of the power sector units is an important issue for the sake of greater national interest. Particularly, the study on financial performance of the units is very much significant which is related to operating efficiency of

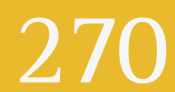


the unit. The researcher, through this investigation, has paid effort to study the problems related to liquidity, profitability and utilisation of fund for creation of assets, revenue generation and expenditure trend.

Review of Literature: Yadav (2011) analysed the progress and problems of power sector in India and Andhra Pradesh. He also assessed the performance of APSPDCL and suggested measures for improvement in the power sector. The paper also highlighted the outcome of the various power sector reform measures undertaken in the state of Andhra Pradesh. In the similar line, Jongpangkumla (2012) analyzed the workings and overall performance of the department of power in Nagaland in order to study the rural electrification in the state and identify the problem faced by the department in generation, transmission and distribution power in the state. The paper examined the organizational and management patterns of the department and evaluated the effect of electricity management in the management of revenue. The study found out that Nagaland does not have any major generation projects and therefore power requirement of the state depends mainly on central sector. The growth rate of the installed capacity has been slow and inadequate during the last 20 years under the study in the state.

Table 1. Analysis of revenue per rupee of expenditure

\begin{tabular}{|c|c|c|c|c|c|c|c|c}
\hline UNITS & $2011-12$ & $2012-13$ & $2013-14$ & $2014-15$ & $2015-16$ & Average & C.V & COR \\
\hline APGCL & 0.9 & 0.99 & 1 & 0.98 & 1.04 & 0.982 & 5.2 & 0.98 \\
\hline AEGCL & 0.86 & 1.26 & 0.99 & 0.87 & 0.76 & 0.948 & 20.3 & 0.57 \\
\hline APDCL & 0.81 & 0.84 & 0.85 & 0.86 & 0.92 & 0.856 & 4.7 & 0.99 \\
\hline
\end{tabular}

Source: Annual Reports of APGCL, AEGCL and APDCL

Table 2. Revenue from Operations on Expenditure (Rs. in crores)

\begin{tabular}{|c|c|c|c|c|c|c|c|c|}
\hline PSUs & Particulars & $\begin{array}{c}2011-12 \\
\text { (in Rs.) }\end{array}$ & $\begin{array}{c}\text { 2012-13 } \\
\text { (in Rs.) }\end{array}$ & $\begin{array}{c}\text { 2013-14 } \\
\text { (in Rs.) }\end{array}$ & $\begin{array}{c}\text { 2014-15 } \\
\text { (in Rs.) }\end{array}$ & $\begin{array}{c}\text { 2015-16 } \\
\text { (in Rs.) }\end{array}$ & $\begin{array}{l}\text { Avg } \\
\text { Ratio }\end{array}$ & $\mathrm{CV}$ \\
\hline \multirow[t]{3}{*}{ APGCL } & Revenue from Operation & 433.96 & 459.7 & 547.05 & 617.5 & 679.7 & \multirow[t]{3}{*}{0.95} & \multirow[t]{3}{*}{$5 \%$} \\
\hline & Expenditure & 491.8 & 479 & 578 & 649 & 664.9 & & \\
\hline & Ratio & 0.88 & 0.96 & 0.95 & 0.95 & 1.02 & & \\
\hline \multirow[t]{3}{*}{ AEGCL } & Revenue from Operation & 391.14 & 536.45 & 456.03 & 462.52 & 537.92 & \multirow[t]{3}{*}{0.83} & \multirow[t]{3}{*}{$22 \%$} \\
\hline & Expenditure & 496.8 & 473.9 & 527.5 & 636.3 & 823.7 & & \\
\hline & Ratio & 0.79 & 1.13 & 0.86 & 0.73 & 0.65 & & \\
\hline \multirow[t]{3}{*}{ APDCL } & Revenue from Operation & 2046.5 & 2301.8 & 2777.2 & 3190.1 & 3664.39 & \multirow[t]{3}{*}{0.76} & \multirow[t]{3}{*}{$6 \%$} \\
\hline & Expenditure & 2914.9 & 3140.4 & 3577.8 & 4120.04 & 4473.07 & & \\
\hline & Ratio & 0.70 & 0.73 & 0.78 & 0.77 & 0.82 & & \\
\hline
\end{tabular}

Source: Annual Reports of APGCL, AEGCL and APDCL

The financial position of the state power section has worsened over the years even though its physical performance has improved slightly over the years. Purkayastha (2012) drew an overview about the power scenario and reform process in the country and several other power related issues. Taking a note on the happenings around the country as a base he dived deep into the power sector restructuring in Assam. He also analysed the operational progress and financial implication of such restructuring in the power sector while Mishra (2013) presented value chain analysis of power sector in India with regard to the current scenario as well as the future prospects. The paper also highlighted that there is a requirement for surge in electricity supply to sustain the rapid economic growth in India and suggested to efficiently manage all the components of value chain. Bhaskar (2016) studied about the development of power sector and the various power sector reforms in Andhra Pradesh. It also dealt with the private sector participation in power sector development and consumer preference.

The study observed that considering the power scenario in the state it is of urgent need to stress on increasing the capacity and maximising the power generation and Sarangi, et.al. (2019) evaluated the sustainability of the Indian electricity sector using a sustainable development framework. The study employed 11 indicators representing three economic, environmental and social dimensions of sustainable development and analysed 12 Indian states over a decade period. The findings of study suggested that the sector is moving towards sustainability although 
deviations exist in the performance of individual states and individual dimensions. Kumar and Majid (2020) presented the significant achievements, prospects, projections and generation of electricity. They also presented the challenges in investment and employment opportunities due the development in the sphere of renewable energy in India. The various obstacles were also identified and the recommendations were made to various stakeholders for improvement of the present situation.

\section{Objectives Of The Study}

The study has the following objectives:

1. To analyse the revenue and expenditures of the power sector units of Assam;

2. To examine the working capital status of these power sector units;

3. To assess the profitability of the power sector units.

\section{RESEARCH METHODOLOGY}

The research study is mainly explorative and analytical in nature based on secondary source of information. Exploration would be made into the profitability, liquidity and other financial aspects of the power sector units which would be analysed to derive correct inferences.

Data presentation tools: The data collected have been presented through charts and diagrams for better interpretation by the users.

Quantitative tools applied: The researcher applied trend analysis, ratio, percentage, annual compounded growth rate, index number and correlation co-efficient for interpreting the data.

Significance Of The Study: In a country which can boast of commercial supply of power just 11years after it was invented, the present scenario is very painful. Again our subcontinent is bestowed with all requisite resources for generation of power. Proper management and distribution of power is very essential to ensure efficient and uninterrupted supply of power. The power sector needs greater attention and systematised planning. The power sector in Assam has undergone great revamp in the last two decades with the Assam State Electricity Board being unbundled into five separate entities which was further merged and formed into three organisations namely Assam Power Generation Company Limited (APGCL), Assam Electricity Grid Corporation Limited (APGCL) and Assam Power Distribution Company Limited (APDCL). There is a tremendous change in the structure of power sector of Assam which has been splitted into three units. Now it is questionable that whether after the reforms, the power sector units are performing well or not. Thus, an evaluative study with regard to the financial aspects of the three power sector units of Assam is pivotal. Financial efficiency of the power sector units can ensure operating efficiency in distribution and generation of power.

\begin{tabular}{l} 
Table 3. Net Working Capital of Power Sector Units (Rs. in Crore) \\
\begin{tabular}{l|c|c|c|c|c|c|} 
PSUs & $\begin{array}{c}2011-12 \\
\text { (in Rs.) }\end{array}$ & $\begin{array}{c}2012-13 \\
\text { (in Rs.) }\end{array}$ & $\begin{array}{c}2013-14 \\
\text { (in Rs.) }\end{array}$ & $\begin{array}{c}2014-15 \\
\text { (in Rs.) }\end{array}$ & $\begin{array}{c}2015-16 \\
\text { (in Rs.) }\end{array}$ & $\begin{array}{c}\text { Average } \\
\text { (in Rs.) }\end{array}$ \\
\hline APGCL & -30.85 & 37.8 & -27.51 & -166.09 & -26.21 & -42.57 \\
\hline AEGCL & 384.93 & 474.07 & 542.23 & 623.75 & 419.7 & 488.94 \\
\hline APDCL & 619.73 & -9072.41 & -721.37 & -1550.09 & -1540.42 & -2452.91 \\
\hline
\end{tabular} \\
\hline
\end{tabular}

Analysis of Revenue and Expenditures of Power Sector Units: Revenues are generated in the power sector units by providing services to the customers. But, the power sector units of Assam are diverse and they carry on their operations in diverse fields like generation, transmission and distribution. APGCL is engaged in the generation of power which is sold to AEGCL who transmits it to APDCL for distribution to each and every household of Assam. AEGCL transmits power from APGCL and delivers it to APDCL which forms their revenue from operations. APDCL comes last in the chain whose principal business activity is to transmit the power purchased from APGCL and other power generating companies to different household and firms in Assam. All these power sector units have also other incomes along with income from business operations.

Revenue generation depends on expenditure incurred by the corporate units. If a corporate unit is running efficiently, the expenditure of this corporation will have definitely high correlation with revenue. Table 1 shows that the expenditure of APGCL and APDCL have high correlation with revenue, i.e. 0.98 and 0.97 respectively, whereas, AEGCL shows moderate correlation coefficient i.e. 0.57.It implies that the expenditure of AEGCL was not leading revenue effectively. Since, the revenue from operation is pivotal to evaluate the performance of the corporate units; therefore, the researcher has attempted to investigate the trend of the ratios in between revenue from operation and expenditure. It has been observed that the growth of revenue against expenditure was not steadily upward in all the aforesaid corporate units. The Table 2 exhibits that the coefficient variance of the ratios was more (i.e., 22\%) in case of AEGCL in comparison to APGCL and APDCL. It again signifies the instability of AEGCL in revenue earning from business operation. 
Table 4. Liquidity position of the power sector units (Rs. in Crores)

\begin{tabular}{|c|c|c|c|c|c|c|c|c|}
\hline PSUs & Ratios & 2011-12 & 2012-13 & 2013-14 & 2014-15 & 2015-16 & Average & $\mathrm{CV}$ \\
\hline \multirow[t]{4}{*}{ APGCL } & Current Ratio & 0.92 & 1.1 & 0.93 & 0.76 & 0.96 & 0.93 & 12.97 \\
\hline & Cash Position Ratio & 0.24 & 0.33 & 0.4 & 0.24 & 0.3 & 0.3 & 22.28 \\
\hline & Current Assets to Total Assets & 0.23 & 0.24 & 0.22 & 0.28 & 0.29 & 0.25 & 12.47 \\
\hline & Current Assets to Fixed Assets & 0.3 & 0.31 & 0.28 & 0.39 & 0.42 & 0.34 & 17.87 \\
\hline \multirow[t]{4}{*}{ AEGCL } & Current Ratio & 1.71 & 1.84 & 1.9 & 1.99 & 1.49 & 1.79 & 10.93 \\
\hline & Cash Position Ratio & 0.74 & 0.56 & 0.56 & 0.52 & 0.3 & 0.54 & 29.15 \\
\hline & Current Assets to Total Assets & 0.57 & 0.52 & 0.48 & 0.48 & 0.45 & 0.5 & 9.18 \\
\hline & Current Assets to Fixed Assets & 1.37 & 1.15 & 0.97 & 0.97 & 0.84 & 1.06 & 19.14 \\
\hline \multirow[t]{4}{*}{ APDCL } & Current Ratio & 1.22 & 0.28 & 0.84 & 0.71 & 0.74 & 0.76 & 44.71 \\
\hline & Cash Position Ratio & 0.72 & 0.14 & 0.38 & 0.29 & 0.26 & 0.36 & 62.09 \\
\hline & Current Assets to Total Assets & 0.56 & 0.53 & 0.57 & 0.44 & 0.46 & 0.51 & 11.71 \\
\hline & Current Assets to Fixed Assets & 1.3 & 1.17 & 1.02 & 0.84 & 0.86 & 1.04 & 19.2 \\
\hline
\end{tabular}

Source: Annual Reports of APGCL, AEGCL and APDCL

Another noticeable fact is that though the average amount of revenue earning of APDCL was more than other two power sector units during the period of the study, the average revenue from business operation of this power sector unit against per rupee of expenditure was lowest among all the power sector units of Assam.

Net Working Capital: Although Net Working Capital is not really a ratio it is often employed as a major tool to assess a company's liquidity position. It is expected that a firm should have a sufficient net working capital in order to be able to meet the claims of its creditors or other recurring needs of the business. Table 3 exhibits the net working capital of the various power sector units of Assam.

It can be found that APDCL reported a very high negative working capital. In the year 2012-13 its net working capital was Rs - 9072.41 crores. Although this negative net working capital came down to Rs -1540.42 crores in 2015-16, it has to be mentioned that APDCL had a negative net working capital during four years under study except in 2011-12 where it has a net working capital of Rs 619.73 crores. APGCL also had a similar picture with a negative net working capital in all the years of study except 2012-13 where it had a net working capital of Rs 37.8 crores. The net working capital of APGCL was Rs -166.09 crore in 2014-15. However it came down to Rs -26.21 crores in 2015-16. It suggests that these two power sector units were resorting to long term borrowings for their operational requirements. AEGCL however maintained a steady net working capital with an average of Rs 488.94 crores during the year of study. Its net working capital in the year 2011-12 was Rs 384.93 crores which rose to Rs 623.75 crores in the year 2014-15. However it came down to Rs 419.7 crores in the year 2015-16 but it had been able to maintain some steadiness in its net working capital.

Liquidity Position Of The Power Sector Units: The theory of liquidity says that an enterprise is liquid, if it holds assets that could be converted into cash or sold by bearing minimum cost or reduction in value. Liquidity at the corporate level is twofold, internal and external. At the internal level it indicates the convertibility of the assets into cash and at the external level it indicates the availability of a ready market where such assets could be converted into cash. The existence of a market highly influences the liquidity of a corporate entity.

The current Ratio of a firm measures the short term solvency or liquidity. It indicates the amount of current assets value against current liability payable. It reflects that APDCL (0.76) and APGCL (0.93) had a very poor liquidity position as it indicates that the current assets are insufficient to meet the current liabilities. These clearly indicate the fact that these power sector units are using a major portion of their long term borrowing to finance their operations and maintenance. In case of AEGCL (1.79) the position was comparatively much better. It could be found during the study that AEGCL (0.54) had a good cash position ratio while APGCL (0.30) had the lowest among the power sector units. It is worth mentionable in this context that APDCL (0.36) has about half of its current assets in the form of cash and cash equivalent. It can thus be deduced from this fact about the extent to which the current liabilites of APDCL is covered by current assets.

The variation in cash position ratio was also highest in case of APDCL (62.09\%) while the lowest variability was reported in APGCL (22.28\%). A high ratio of current assets to total assets will lead to access amount blocked up in current assets and adversely affects profitability and operations. APGCL (0.25) maintained the lowest ratio while APDCL (0.51) had the highest current ratio to total assets. It implies that the position of APGCL is better than that of AEGCL and APDCL. AEGCL (1.06) had the highest ratio followed by APDCL (1.04) and in both these units the current assets exceeds the fixed assets. This was mostly because of high amount of trade receivables in 
both the power sector units. In addition to that APDCL also had a huge amount blocked in the form of cash and cash equivalent during the period under study. APGCL (0.34) maintain a substantially low ratio of current assets to fixed assets. It is also worth mentioning that APDCL $(19.20 \%)$ and AEGCL (19.14\%) had shown fluctuating behavior in its ratio current assets.

Effectiveness of the Power Sector Units in Utilising Its Current Assets and Working Capital: The liquidity ratio generally relates to the liquidity of the entire firm. However liquidity can be examined in a better way to determine the rate at which current assets are converted into cash, such ratios are the turnover ratios or activity ratios. Activity ratios are determined on the basis of revenue from operations, hence these ratios are also known as turnover ratio. It indicates the rate on intensity with which the capital employed is circulated in the process of business operation. These ratios show the efficiency with which working capital and inventory is utilised to generate revenue. Higher the turnover ratio better is the utilisation of resources, which enables the firm to earn higher profits.

Table 5. Effectiveness of Working Capital of the power sector units (Rs. in Crores)

\begin{tabular}{|c|c|c|c|c|c|c|c|c|}
\hline PSUs & Ratios & 2011-12 & 2012-13 & 2013-14 & 2014-15 & 2015-16 & Average & $\mathrm{CV}$ \\
\hline \multirow[t]{4}{*}{ APGCL } & Inventory Turnover Ratio & 5.8 & 5.62 & 11.74 & 9.12 & 4.09 & 7.27 & 42.61 \\
\hline & Trade Receivables Turnover Ratio & 5.8 & 5.62 & 11.74 & 9.12 & 4.09 & 7.27 & 42.61 \\
\hline & Working Capital Turnover Ratio & 1.31 & 1.2 & 1.6 & 1.25 & 1.14 & 1.3 & 13.81 \\
\hline & $\begin{array}{l}\text { Cash from Operations to } \\
\text { Revenue from Operations }\end{array}$ & 0.12 & 0.05 & 0.15 & 0.03 & -0.08 & 0.056 & 157.45 \\
\hline \multirow[t]{4}{*}{ AEGCL } & Inventory Turnover Ratio & 6.03 & 22.46 & 20.64 & 23.4 & 31.81 & 20.87 & 44.76 \\
\hline & Trade Receivables Turnover Ratio & 1.54 & 1.48 & 1 & 0.94 & 0.92 & 1.18 & 26.11 \\
\hline & Working Capital Turnover Ratio & 0.46 & 0.58 & 0.46 & 0.44 & 0.49 & 0.49 & 11.09 \\
\hline & $\begin{array}{l}\text { Cash from Operations to } \\
\text { Revenue from Operations }\end{array}$ & 0.19 & -0.04 & -0.03 & -0.15 & 0.01 & -0.003 & -4553.8 \\
\hline \multirow[t]{4}{*}{ APDCL } & Inventory Turnover Ratio & 17.57 & 15.71 & 13.71 & 11.85 & 10.94 & 13.96 & 19.53 \\
\hline & Trade Receivables Turnover Ratio & 4.29 & 3.9 & 3.8 & 3.9 & 3.71 & 3.92 & 5.73 \\
\hline & Working Capital Turnover Ratio & 0.7 & 0.76 & 0.81 & 0.94 & 0.95 & 0.83 & 13.35 \\
\hline & $\begin{array}{l}\text { Cash from Operations to } \\
\text { Revenue from Operations }\end{array}$ & -0.06 & -0.2 & 0.18 & 0.04 & 0.05 & 0.002 & 6232.66 \\
\hline
\end{tabular}

Source: Annual Reports of APGCL, AEGCL and APDCL

Table 6. Profitability Analysis of the power sector units (Rs. in Crores)

\begin{tabular}{|c|c|c|c|c|c|c|c|c|}
\hline PSUs & Ratio & 2011-12 & 2012-13 & 2013-14 & 2014-15 & 2015-16 & Average & $\mathrm{CV}$ \\
\hline \multirow[t]{3}{*}{ APGCL } & Gross Profit and Loss Ratio & 0.23 & 0.2 & 0.28 & 0.25 & 0.31 & 0.26 & 15.71 \\
\hline & Net Profit and Loss Ratio & -0.11 & -0.01 & -0.15 & -0.002 & 0.001 & -0.06 & -128.5 \\
\hline & Operating Profit Ratio & -0.05 & -0.06 & 0.04 & 0.05 & 0.11 & 0.02 & 375.6 \\
\hline AEGCL & Gross Profit and Loss Ratio & 0.28 & 0.42 & 0.3 & 0.1 & -0.09 & 0.2 & 97.33 \\
\hline \multirow{5}{*}{ APDCL } & Net Profit and Loss Ratio & -0.16 & 0.2 & -0.01 & -0.14 & -0.32 & -0.09 & -222.2 \\
\hline & Operating Profit Ratio & -0.06 & 0.22 & 0.01 & -0.11 & -0.26 & -0.04 & -421.73 \\
\hline & Gross Profit and Loss Ratio & -0.08 & -0.02 & 0 & 0.01 & 0.05 & -0.01 & 491.25 \\
\hline & Net Profit and Loss Ratio & -0.17 & -0.16 & -0.17 & -0.16 & -0.03 & -0.14 & -45.96 \\
\hline & Operating Profit Ratio & -0.11 & -0.05 & -0.04 & -0.03 & 0.02 & -0.04 & -121.28 \\
\hline
\end{tabular}

Source: Annual Reports of APGCL, AEGCL and APDCL

The inventory turnover ratio of AEGCL (20.87 times) had the highest inventory turnover ratio, but it also had the highest variation of $44.76 \%$ during the year under study. Although 8 times is considered to be an ideal inventory turnover ratio and most of the power sector units have a ratio more than or around that ideal ratio, it cannot be significantly concluded about a good liquidity position. The inventory turnover ratio of APGCL was 7.27 times while that of APDCL was 13.96 times. It must be understood that the power sector units are not trading concerns and do not necessarily require to maintain a high inventory. Inventories at the disposal of the power sector units are mostly spares and operations and maintenance materials which compliment the transmission process. The power sector units of Assam generate, transmit and distribute power to the households 
and firms within the state. APGCL sells power to APDCL and thus most of its receivables are from APDCL. AEGCL transmits the power from the power plants to power station maintained by APDCL and thus their receivables also comprise mostly from APDCL. APGCL (7.27 times) has the highest turnover ratio among the power sector units while AEGCL (1.18 times) has the lowest.

In the year 2013-14, APGCL had a turnover ratio 11.74 times but it came down subsequently to 4.09 times in 2015-16. As a result, in case of APGCL it had been found to have a variation of $42.61 \%$ in its trade receivables turnover ratio. The revenue of both these power sector units is generated from APDCL and they could not maintain a strict credit control policy towards APDCL. APDCL (5.73\%) however had maintained a reasonable trade receivable turnover ratio among the power sector units of Assam during the period under study. Among all the power sector units APGCL (1.30 times) had the highest working capital turnover ratio while AEGCL (0.49 times) had the lowest. However, the degree of fluctuation was also the lowest in case of AEGCL (11.09\%). AEGCL had a very low working capital turnover ratio and that remained subsequently stable during all the five years under study. The investment of funds in working capital of AEGCL is almost double its revenue generation in a financial year. This must be seriously considered by the management so that such working capital can be reduced to avoid unnecessary blockage of funds and pressure on profitability. AEGCL must improve their credit policy and at the same time improve their working capital turnover ratio.

Surprisingly it could be found that some of the power sector units had a cash outflow during the years under study. Such a result is a clear indication of the degree at which these power sector units perform. In case of AEGCL $(-0.003)$, the average ratio of the 5 years under study indicated a negative figure. Among all the power sector units APGCL (0.05) could be said to have the best ratio of cash from operations to revenue from operations. It reported a positive value in four out of five years under study. In any way, concluding about the power sector of Assam, such a ratio of Cash from operations to Revenue from operation points at serious anomalies.

Profitability Analysis of The Power Sector Units: Profitability is the primary basis for any managerial decision. It has much more managerial uses than profit itself. It is the measure of overall organizational efficiency in achieving business goals. Not only to the organization as whole, it is also employed to measure departmental efficiency in case of organization in many departments. Profitability also helps to ascertain the level of activity at which the optimum position can be attained. Often it is found that profit increases with the rise in the level of activity but the rate of profitability comes down. In such a case the onus is on the managerial body to find out the level of activity at which both profit and profitability reaches the highest level. The profitability analysis also ensures an appropriate product mix and sales mix. Measurement of profitability or quantification of profitability is very crucial for any business enterprise.

Table 5 exhibits the gross profits of the power sector units. It could be found that during the years under study APDCL could not maintain even gross profit during 201112 and 2012-13. During the 5 years under study APDCL had an average gross loss ratio of -0.01. APGCL however maintained a gross profit during the years under study with average of 0.26 from 2011-12 to 2015-16. The gross profit ratio of APGCL is very low and it is impossible to cover the administrative and selling expenses with such a low gross margin profit. APGCL could earn a net profit only in the year 2015-16 whereas AEGCL earned profit only in the year 2012-13. APDCL could not exhibit profit in the period of the study.

The net results of these power sector units were fluctuating too due to instability in the cost incurred by different activity centres. Further, it could be found that both AEGCL and APDCL had operating loss ratio (i.e., net average loss) during the year under study. APGCL was the only power sector unit of Assam which could maintain an operating profit ratio. During 2015-016 APGCL had operating profit 0.11. Such operating losses are mainly due to extremely high cost of functioning. APDCL could not even maintain a gross profit and thus the question of an operating profit does not even arise. APGCL had an average gross profit ratio of 0.26 during the period under study which came down to a 0.02 as the operating profit ratio. This brings to light the high amount spent on functioning of the organizations. In the year 2012-13 AEGCL had an operating profit ratio 0.22 which was the highest among all the power sector units of Assam. However, it had shown a highly fluctuating behaviour with a coefficient of a variation of 421.73\%. The operating profit ratio of AEGCL in the year 2015-16 was -0.26 .

\section{FINDINGS AND CONCLUSION}

During the years under the study, the power sector units earned losses in most of the years. The growth in expenses was found to be more than the growth in revenue in some case. The power generating unit did not have any significant growth in the power generating capacity. In addition to that, it also had depletion in its fixed tangible assets. The financial health moved from worse to worst but the most surprising fact was that such losses were highly variable. One company earns a very high profit during one of the years under study from a huge loss in the previous and again plunging into losses in the next year. This highlights the unpredictability of returns. The liquidity position of all the companies was very poor.

The power sector units had a negative working capital in most of the years under study. The proportion of direct expenses was so high that it left very small margin to cover the operational and administrative expense. Most of these power sector units had a high dependence on external borrowing and grant but the total amount of 
reserves are continuously depleting due to recurring losses. Further, some of the power sector units have a high amount of trade receivables which reduces its dependence on own funds. There has been a continuous increment in the grants received by the power sector units but such operational inefficiencies are consuming such grants year after year and is not leading to any kind of value addition in the power sector units. The various stakeholders namely, the Government, Regulatory Commission and the power sector units must go through serious consideration to revive the power sector units.

\section{REFERENCES}

Jongpankumla (2015). Performance evaluation of power sector in Nagaland: An analytical study (19902006) (Doctoral Dissertation, Nagaland University, Lumami, India). Retrieved from http://hdl.handle. net/10603/55911

Kardam, S. (2016). Power Sector Reforms in India with special reference to Madhya Pradesh (Doctoral Dissertation, Devi Ahalya Viswavidyalaya, Indore, India). Retrieved from http://hdl.handle.net/10603/111787

Kumar, C. \& Majid, M. (2020). Renewable energy for sustainable development in India: Current status, Future prospects, Challenges, Employment and Investment opportunities, Energy, Sustainability and Society, 10(2). doi: https://doi.org/10.1186/s13705-019-0232-1

Mushahid, S. (2018). A study on financial performance of National Thermal Power Corporation Limited (Doctoral Dissertation). Aligarh Muslim University, Aligarh, India.

Purkayastha, P. (2012). Restructuring of Power sector in Assam (Doctoral Dissertation, Gauhati University, Guwahati, India). Retrieved from http://hdl.handle. net/10603/114326

Rao, N. S. (2014). Impact of power sector reforms in Andhra Pradesh and causes of the continuing power crisis (Doctoral Dissertation, Acharya Nagarjuna University, Guntur, India). Retrieved from http://hdl. handle.net/10603/31037

Sarangi, G., Mishra, A., Chang, Y. \& Hesary, F. (2019). Indian electricity sector, energy security and sustainability: An empirical assessment, Energy Policy, 135. doi:https://doi.org/10.1016/j.enpol.2019.110964 Yadav, R. (2011). Progress and problems of power sector in Andhra Pradesh with special reference to APSPDCL (Doctoral Dissertation, Sri Krishnadevaraya University, Anantapur, India). Retrieved from http://hdl.handle. net/10603/63221 